九州大学学術情報リポジトリ

Kyushu University Institutional Repository

\title{
Zircon Overgrowths in the Ryôke Metamorphic Zone of the Yanai Area, Southwest Japan
}

Karakida, Yoshifumi

Faculty of Sciences, Kyushu University

https://doi.org/10.5109/1526106

出版情報：九州大學理學部紀要：Series D, Geology. 10 (2)，pp.59-72, 1961-03-10. Faculty of Science, Kyushu University バージョン：

権利関係 : 
Mem. Fac. Sci., Kyushu Univ., Ser. D, Geology, Vol. X, No. 2, pp. 59-72, tables 1-3, text-fig. 1, pls. 9-10, March 10, 1961

\title{
Zircon Overgrowths in the Ryôke Metamorphic Zone of the Yanai Area, Southwest Japan*
}

By

\author{
Yoshifumi KARAKIDA
}

\begin{abstract}
The Ryôke metamorphic terrain of the Yanai area, Southwest Japan, consists of non-metamorphosed sediment zone, biotite schist zone, and banded gneiss zone, and the older Ryôke granodiorites and the younger Ryôke granites. Zircon overgrowths sometimes found in the zircon concentrates from granitized banded gneisses and granitic rocks are divided into three types according to morphological forms of core and shell: $\mathrm{O}-\mathrm{A}, \mathrm{O}-\mathrm{B}$, and $\mathrm{O}-\mathrm{C}$. The relations between the overgrowth type and the enclosing rock type as well as characteristic features of each overgrowth type were examined in detail. These investigations. reveal that the zircon overgrowths were originated by mixing, in a broad sense, of sediments and granitic liquids and by the subsequent contamination of granitic magma, and that characters of the overgrowth may indicate the conditions of mixing and contamination.
\end{abstract}

\section{Contents}

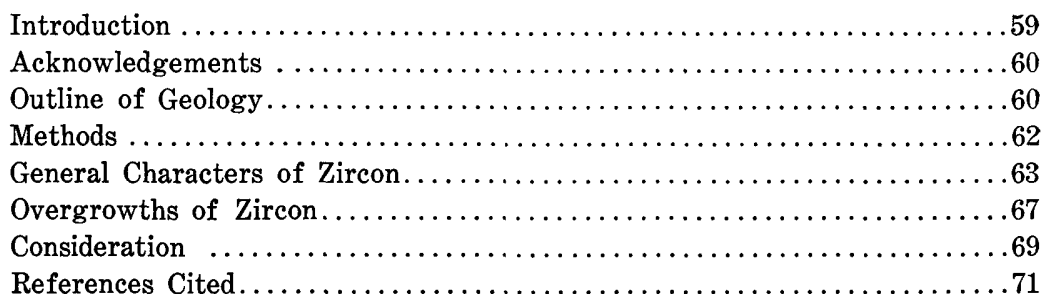

\section{Introduction}

During my petrological studies of zircon in Japanese igneous and metamorphic rocks, some overgrown crystals were found in the granitized gneisses and granitic rocks of the Ryôke metamorphic zone in the Yanai area, Southwest Japan. Since this area is a representative of the metamorphic zone just mentioned, it has been geologically investigated in detail by SATo (1933), IwAo (1936, 1940), KoJima and OKamura (1952), and OKamura (1957). In this paper are described overgrowth phenomena in zircon of the rocks in question and is presented a preliminary consideration as to a petrologic meaning of 
such overgrowths, though much more extensive and exhaustive investigations are demanded before the formation of the rocks concerned can be thoroughly explained.

\section{Acknowledgements}

I wish to express my gratitude to Professor Tôru Tomrta, of our Department, who has given me excellent advice and helpful criticism during this study and employed his spare time in reading the manuscript and correcting my English writing. I am greatly indebted to Mr. Yoshihiko OKAmuRA of Yamaguchi University for giving me permission to make full use of his geologic map of this area and showing me round the type localities of various rock types, and to Professor Tatsuro MATsumoto and Assistant Professor Sadakatsu TANEDA of our Department and Professor George KoJima of the Department of Geology and Mineralogy, Hiroshima University, for their helpful discussion and suggestion during the periods of field survey and laboratory work. I am also much obliged to Messrs. Masamoto ÔIshi, Takao Hosaka, and Hisakazu OGURI, who have courteously placed at my disposal some of their rock collection.

This work was partly financed by the Grant in Aid for Scientific Researches from the Ministry of Education, Japan.

\section{Outline of Geology}

The Yanai area is one of the representative fields of the Ryôke metamorphic zone in Southwest Japan. KoJIMA and OKAmURA (1952) and OKamurA (1957) divide the metamorphic complex of this area into three progressive zones, from north to south: (1) non-metamorphosed sediment zone, (2) biotite schist zone, (3) banded gneiss zone; they also divide the associated granitic rocks into two distinct groups: the older Ryôke granodiorites (ôbatake and Gamano granodiorites) and the younger Ryôke granites (Tôwa, Kibe, and Murotsu granites). These geologic units, as a whole, roughly show a zonal arrangement extending in the east-west direction, though it is somewhat disturbed by blockmovement and granite intrusion of later periods.

The age of the Ryôke metamorphic rocks is currently believed to be late Paleozoic or early Mesozoic (KoJIma, 1953; OKAmURA, 1957), though no conclusive evidence of this assignment seems to be found.

The non-metamorphosed sediment zone.-This zone is composed mainly of "thick beds of banded chert" alternating with thin beds of slate and sandstone (KoJima, 1953). Small lenses of limestone, schalstein, and diabase are also found.

The biotite schist zone.-This zone is composed mainly of banded siliceous biotite schist and biotite schist. The majority of rocks in this zone suffer intensely from thermal polymetamorphism by the Hiroshima granite of Cretaceous age, the intrusion of which does not appear to be directly related to the 
Ryôke metamorphism and plutonism proper. Thus, the rock characters which were developed by the Ryôke metamorphism proper are generally obscure now.

The banded gneiss zone.-The rocks of this zone are characterized by the banded structure due to alternation of a few centimeters of leucocratic (quartzofeldspathic) bands or lenses and melanocratic (biotite-rich) layers. Generally speaking, in the banded gneisses of pelitic origin the white bands show more intense micro-folding and are, as a whole, smaller in thickness but more conspicuously variable than those in the siliceous gneisses derived from "banded chert." These rocks consist mainly of quartz, biotite, plagioclase, potash feldspar, muscovite, sillimanite, cordierite, and garnet, proportions of these minerals being variant from specimen to specimen taken from different localities. Besides these main rock types intercalating thin seams and lenses of amphibolite rarely occur as well.

Not only adjacent to the contact with the older Ryôke granodiorites (obatake and Gamano granodiorites) but also in the xenolithic fragments in them, the banded gneisses are so granitized as to show diverse rock facies intermediate between typical gneiss and granodiorite. It is to be noted that these xenolithic fragments are, according to OKAMURA (1957), the remnants preserved from granitization by which the granodioritic masses were formed.

The ôbatake granodiorite.-This granodiorite, keeping concordant and harmonic relations to the adjacent country rocks, occurs in the banded gneiss zone as thin long belts or isolated small lenticular bodies. The rock, consisting essentially of plagioclase, quartz, biotite, and potash feldspar, sometimes with varying amounts of muscovite, sillimanite, or cordierite, is medium-grained and shows a gneissic structure as a whole, but it is variable in grain size, in the proportion of constituent minerals, and in the degree of gneissic structure. In addition, the bodies of this granodiorite have many xenolithic gneisses and "basic inclusions" which have been digested in various degrees. Such a heterogeneity is one of the characteristic features of this geologic unit.

KoJima and OKAmura (1952) and OKAmURA (1957) have regarded this granodiorite as a product of granitization "in situ" of pelitic sediments (or banded gneisses) on the basis of the following field evidences: structural harmony between this rock and the adjacent gneiss, gradation in appearance from one rock facies to the other in the strike direction, and heterogeneity of rock characters in the granodiorite body itself.

The Gamano granodiorite.-This granodiorite is mainly developed in the southern part of this area. Its concordant relation to the country rocks is generally noted, and its "flow structure" is in harmony with the schistose or banded structure of the surrounding metamorphics and the xenolithic blocks. "This granodiorite is generally coarser in grain size and weaker in the gneissic structure than the obatake granodiorite. It is composed mainly of plagioclase, quartz, potash feldspar (usually subordinate to plagioclase), and biotite, sometimes with varying amounts of common hornblende, muscovite, pyroxene, garnet, etc. 
"Basic inclusions" and the banded gneiss xenoliths of various sizes are commonly found, and in places biotite-rich schlierens which may be attributed to further assimilation of the "basic inclusions" and banded gneiss xenoliths. just mentioned are also met with. Here, for convenience of description, the granodiorite under consideration is classed into (1) the Gamano granodiorite. A (Gamano GD-A), which is free from biotite-rich schlierens, and (2) the Gamano granodiorite B (Gamano GD-B), which contains the schlierens. This: Gamano GD-B so strongly resembles the ôbatake granodiorite already described that even careful observation of hand-specimen cannot distinguish one from the other.

OKAMURA (1957) offered the opinion that the Gamano granodiorite is a parautochthonous granite produced through granitization followed by mobilization.

The Kibe granite.-This is a representative of the younger Ryôke granites, which are largely developed cutting discordantly across the structures of both the older Ryôke granodiorites and the metamorphic zones. It is coarse-grained, weakly foliated, and adamellitic in composition. It consists mainly of potash: feldspar, plagioclase, quartz, biotite, and muscovite.

\section{Methods}

Preparation.-Zircon concentrates to be examined were obtained from about fifty rock-samples collected from almost all of the geologic units mentioned above; rocks in the biotite schist zone, which has undergone the intense thermal metamorphism by the Cretaceous granite, was excluded, because the characteristic features due to the Ryôke metamorphism proper might be destroyed to a certain extent.

Separation.-The following procedure was used in separating zircons from rocks. About $1 \mathrm{~kg}$ of rock (fresh or more or less weathered) are crushed with a stamp crusher to pass through a 50 mesh sieve $(0.279 \mathrm{~mm}$ opening $)$. The rockpowder is divided into several fractions which are treated separately. Each fraction is put into a $1000 \mathrm{cc}$ beaker, water is poured into the bearker, and afteragitating the mixture of rock-powder and water dust particles and lighter minerals such as quartz and feldspars are washed away from the beaker. This is repeated several times until almost all of lighter minerals are removed. The heavy residues thus obtained are put together in a $300 \mathrm{cc}$ beaker. Next the material is gently boiled with conc. $\mathrm{HCl}$ for about 10 minutes to solve apatite and to clean the surfaces of zircon; then washed with water. Again it is gently boiled with $\mathrm{HNO}_{3}$ for about 10 minutes to decompose pyrite, when present, washed, and dried. By these chemical treatments zircon does not undergo any notable change in size and color (Tomita and KARAKIDA, 1956, p. 24). After removing the magnetic minerals by means of a Frantz isodynamic separator, other minerals which prevent careful and exact observations of zircon are removed by hand picking from the residue. Thus concentrates of practically 
pure zircon are obtained.

Mounting.-A crop taken at random from the final concentrates of zircon is permanently mounted on a clean slide glass with Canada balsam. Now it is much to be regretted that many of the crystals are apt to move towards the sides of the slide on pressing down the cover glass. In order to distribute the crystals evenly over the slide, the following operation is undergone before adding Canada balsam: one or two drops of distilled water are carefully placed over the zircon crop on the slide, and while gently heating the water to evaporate, the crystals are uniformly dispersed with a needle. When this is done, they will adhere to the slide glass (KRUmbein and PettiJohn, 1938, p. 360).

Measurements.-Both length and breadth are measured of each doubly terminated crystal encountered at equally spaced intervals. Linear traverses are made with a mechanical stage so as to cover the entire slide. As already suggested by POLDERVAART (1955, p. 436), measurements of about 200 crystals are normally sufficient, and care should be taken that spaced intervals are wide enough to exclude previously measured crystals.

\section{General Characters of Zircon}

Brief description of general characters of zircon in question is given here.

Abundance.-Even rough comparisons of the zircon crops from various rocks in this area reveal that the amount of zircon much differs among different geologic units, which, in ascending order of abundance, are the non-metamorphosed sediment, the banded gneiss, the xenolithic banded gneiss, and the granitic rock-this may imply some deep relationship between the amount of zircon and the origin of rocks that contain it.

Zircons are most abundant in the ôbatake granodiorite, the Gamano granodiorites $\mathrm{A}$ and $\mathrm{B}$, and the Kibe granite, being of roughly the same amount as those in granites of the other areas I studied. The non-metamorphosed sediments generally contain a few zircons: none or only scores to hundreds of grains were recovered from about $1 \mathrm{~kg}$ of the crushed banded cherts; zircons are far more abundant in the sandstones than in the banded cherts but only half of the amount of those in the granitic rocks; in the slates zircon varies in amount from specimen to specimen, being between those in the cherts and the sandstones. Zircons in the banded gneisses are of nearly the same amount as those in the non-metamorphosed sediments. The xenolithic banded gneisses except the siliceous variety are richer in zircon than the banded gneisses but generally poorer than the granitic rocks.

Zircon types.-In the non-metamorphosed sediments different varieties of zircons are present in varying proportions: they are colorless, pale brownish gray, and strongly pleochroic purple in transmitted light. In the slates, however, colored zircons are less in amount than colorless one. It is very interesting to note that all the zircons in the banded gneisses are seen colorless in transmitted light. They show varying degrees of rounding and fracturing as those 


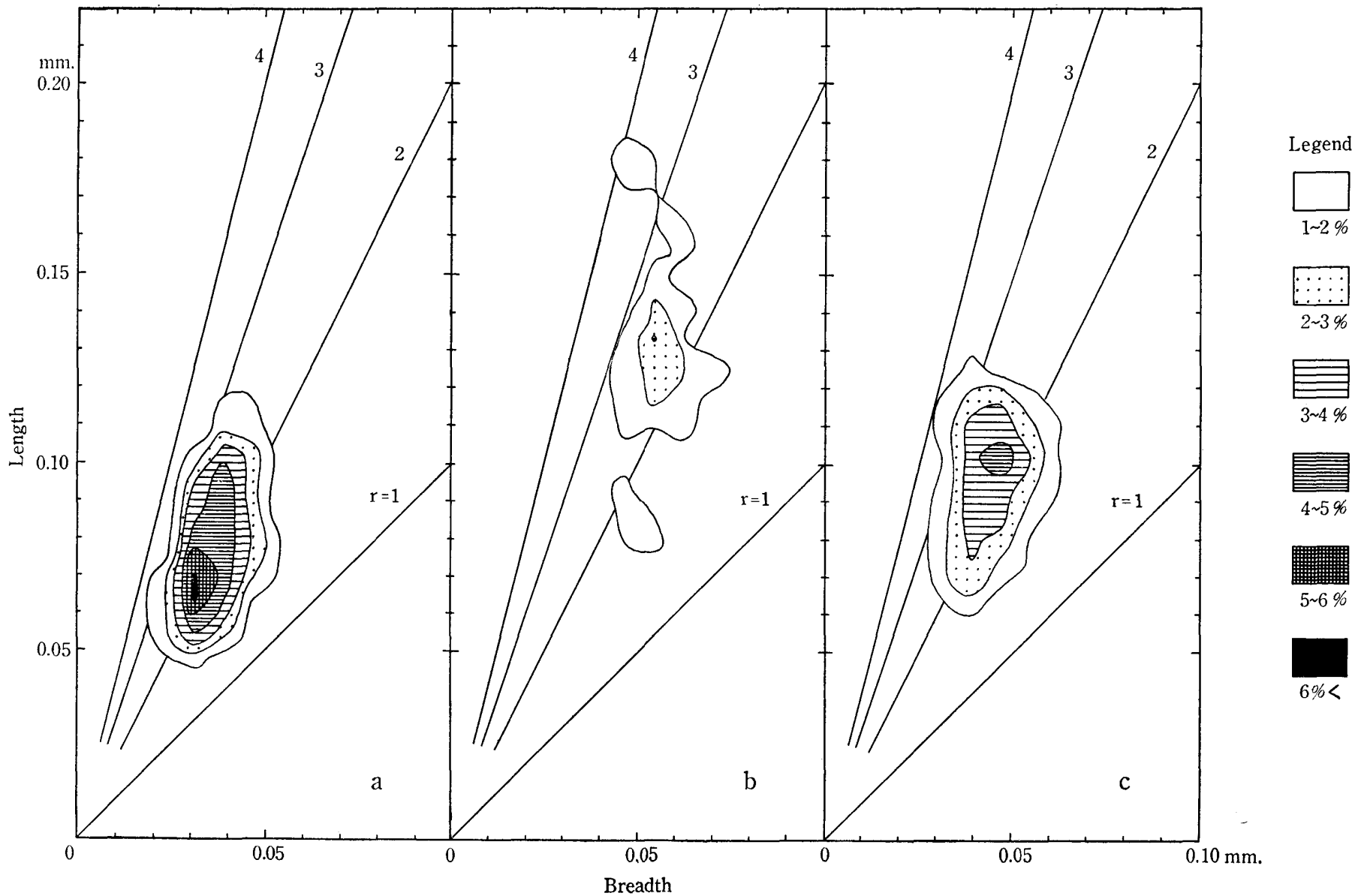

Fig. 1. Length-breadth diagrams of zircon crystals in different concentrates as a representative of each zircon type a: Zircon type I (Xenolithic gneiss, Yn 30) c: Zircon type III (Kibe granite, Yn 337)

b: Zircon type II (Ôbatake granodiorite, Yn 153)

$r$; Length/breadth 
in the non-metamorphosed sediments, though some few euhedral crystals are also present. Elongated and metamict zircons, which are common in the granitic rocks in this area, occur only in an extremely low proportion in the nonmetamorphosed sediments and the banded gneisses.

Presenting a striking contrast to the rounded form of detrital zircons in the non-metamorphosed sediments and the banded gneisses described above, zircons in the rocks ranging from the xenolithic gneiss to granite are euhedral and show little difference in color. Each individual of the zircons from these geologic units may be classed into three types according to their crystal forms whose diagnostic characters are summarized in Table 1 . Figure 1 shows the

Table 1. Zircon types

\begin{tabular}{|c|c|c|c|c|c|}
\hline $\begin{array}{l}\text { Character } \\
\text { Type }\end{array}$ & \multicolumn{2}{|l|}{ Habit } & \multicolumn{2}{|c|}{$\begin{array}{l}\text { Size Elongation } \\
\text { (See Fig. 1) }\end{array}$} & Other characters \\
\hline Z-I & $\begin{array}{l}\text { Highly faced (football- } \\
\text { shaped): large } x \text {; domi- } \\
\text { nant } a, m ; \text { small } p ; \\
\text { rare } c\end{array}$ & $\frac{+}{0}$ & $\begin{array}{l}\text { Rather } \\
\text { small }\end{array}$ & Moderate & $\begin{array}{l}\text { Fresh. Usually colorless in } \\
\text { transmitted light. Inclu- } \\
\text { sions: common, generally } \\
\text { finer than those in Z-II }\end{array}$ \\
\hline Z-II & $\begin{array}{l}\text { Long prismatic (pencil- } \\
\text { shaped): dominant } a, m \text {, } \\
p ; \text { large or small } x ; \\
\text { rare } c\end{array}$ & 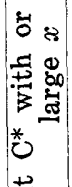 & $\begin{array}{l}\text { Large to } \\
\text { moderate }\end{array}$ & Large & $\begin{array}{l}\text { Generally fresh, sometimes } \\
\text { metamict. Usually color- } \\
\text { less in transmitted light. } \\
\text { Inclusions: less in amount } \\
\text { than those in Z-I but } \\
\text { larger in size }\end{array}$ \\
\hline Z-III & $\begin{array}{l}\text { Dominant } a, m, p ; \text { small } x \\
\text { sometimes } c\end{array}$ & E. & Moderate & Mederate & $\begin{array}{l}\text { Commonly metamict. } \\
\text { Cloudy or dark. Usually } \\
\text { irregular cracks }\end{array}$ \\
\hline
\end{tabular}

$p:(111) ; \quad x:(311) ; \quad a:(100) ; \quad m:(110) ; \quad c:(001)$

* This type of crystal habit has been defined by Tomita and KARAKIDA $(1958$, p. 27).

relation between lengths and breadths of the euhedral zircons in (a) the xenolithic banded gneiss characterized by the zircon type I (Z-I), (b) the ôbatake granodiorite characterized by the zircon type II (Z-II), and (c) the Kibe granite characterized by the zircon type III (Z-III).

Zircon assemblage.- The zircon concentrates from the specimens ranging from the xenolithic banded gneiss to the Kibe granite are classified into five groups according to assemblages of the three zircon types mentioned above as follows :

Assemblage 1 (ZA1): Z-I only, or sometimes with a few of Z-II

Assemblage 2 (ZA2): Z-I and Z-II

Assemblage 3 (ZA3): Z-II with a few of Z-I and Z-III

Assemblage 4 (ZA4): Z-I and Z-III

Assemblage 5 (ZA5): Z-II and Z-III

Assemblage 6 (ZA6): Z-III with or without Z-II

Relation between zircon assemblage and rock type.-The zircon assemblages just mentioned may be related to the rock types or modes of rock formation (Table 2). 
Table 2. Relative abundance of the three types of zircon

\begin{tabular}{|c|c|c|c|c|c|c|c|c|c|c|c|c|}
\hline Z. assemblage & \multicolumn{4}{|c|}{$\mathrm{ZA1}$} & \multicolumn{4}{|c|}{$\mathrm{ZA2}$} & \multicolumn{4}{|c|}{ ZA3 } \\
\hline Rock type $\quad *$ & $\mathrm{~N}$ & A & B & $\mathrm{C}$ & $\mathrm{N}$ & A & B & $\mathrm{C}$ & $\mathrm{N}$ & A & B & $\mathrm{C}$ \\
\hline $\begin{array}{c}\text { Xenolithic } \\
\text { banded gneiss }\end{array}$ & $\begin{array}{l}\text { Yn } 30 \\
\text { Yn } 45 \mathrm{a} \\
\text { Yn } 345 \mathrm{~b} \\
\text { Yn } 353 \mathrm{~b}\end{array}$ & $\begin{array}{l}0.5 \\
0 \\
0 \\
0.5\end{array}$ & $\begin{array}{l}2.5 \\
0.5 \\
3 \\
6.5\end{array}$ & $\begin{array}{l}0 \\
0 \\
0 \\
1\end{array}$ & Yn 247 & 2.5 & 6 & 1.5 & & & & \\
\hline $\begin{array}{c}\text { Ôbatake } \\
\text { granodiorite }\end{array}$ & $\begin{array}{l}\text { K } \\
\text { Yn } 341 \\
\text { Yn } 361 \text { a } 3\end{array}$ & $\begin{array}{rr}>0 \\
1 \\
39 & 2\end{array}$ & $\begin{array}{r}5 \\
2 \\
22\end{array}$ & $\begin{array}{l}0 \\
0 \\
0\end{array}$ & Yn 362 & 6 & 6 & 0 & $\begin{array}{l}\text { II } \\
\text { Yn } 153 \\
\text { Yn } 345\end{array}$ & $\begin{array}{l}0 \\
0 \\
0\end{array}$ & $\begin{array}{l}16 \\
0.5 \\
2\end{array}$ & $\begin{array}{l}0 \\
0 \\
0\end{array}$ \\
\hline$\underset{\text { gramodiorite B }}{\text { Gamano }}$ & & & & & & & & & $\begin{array}{l}\text { Yn } 245 \mathrm{a} \\
\text { Yn } 250\end{array}$ & $\begin{array}{l}2 \\
0\end{array}$ & $\begin{array}{l}57.5 \\
27\end{array}$ & $\begin{array}{r}2 \\
25\end{array}$ \\
\hline \multicolumn{13}{|l|}{$\underset{\text { granodiorite } \mathrm{A}}{\text { Gamano }}$} \\
\hline Kibe granite & & & & & & & & & & & & \\
\hline
\end{tabular}

* $\mathrm{N}$ : Number of rock specimen; A, B, and C: content of the overgrowth

Of five specimens of the xenolithic banded gneiss four have ZA1 and only one ZA2. The rock characterized by the latter assemblage, which occurs as a small xenolithic lens about $30 \mathrm{~cm}$ thick in the Gamano GD-B, has apparently been more highly assimilated than the rocks of ZA1.

Among the rocks belonging to the ôbatake granodiorite, those of ZA1 show a well-developed banded structure due to rather roughly alternating white and gray bands, but its structure presents a weaker contrast in color and more obscure boundaries than in the typical banded gneisses, while those of ZA3, which is medium-grained and uniformly foliated, are so similar to the Gamano GD-B of ZA3 that it is very difficult to distinguish between them in hand specimensit is possible only by field observations.

Among the rocks of the Gamano GD-B, those of ZA3 are medium-grained, moderately foliated, and comparatively homogenous in appearance, while those of ZA4 contain thin biotite-rich lamellae or films. In these rocks Z-III scarcely displays metamict state, which is common in those from the Gamano GD-A and the Kibe granite.

The zircons in the Gamano GD-A are of either ZA5 or ZA6. According to this fact, the granodiorites may be classed into two groups, which cannot be distinguished by the ordinary petrological methods and geological observations. In general the pyramid $x$ (311) of Z-II is developed smaller in the Gamano GD-A than in the GD-B.

In ZA6 of the Kibe granite Z-II is smaller in amount than in ZA6 of the 
overgrowths $(\mathrm{O}-\mathrm{A}, \mathrm{O}-\mathrm{B}$, and $\mathrm{O}-\mathrm{C})$ in Yanai rocks

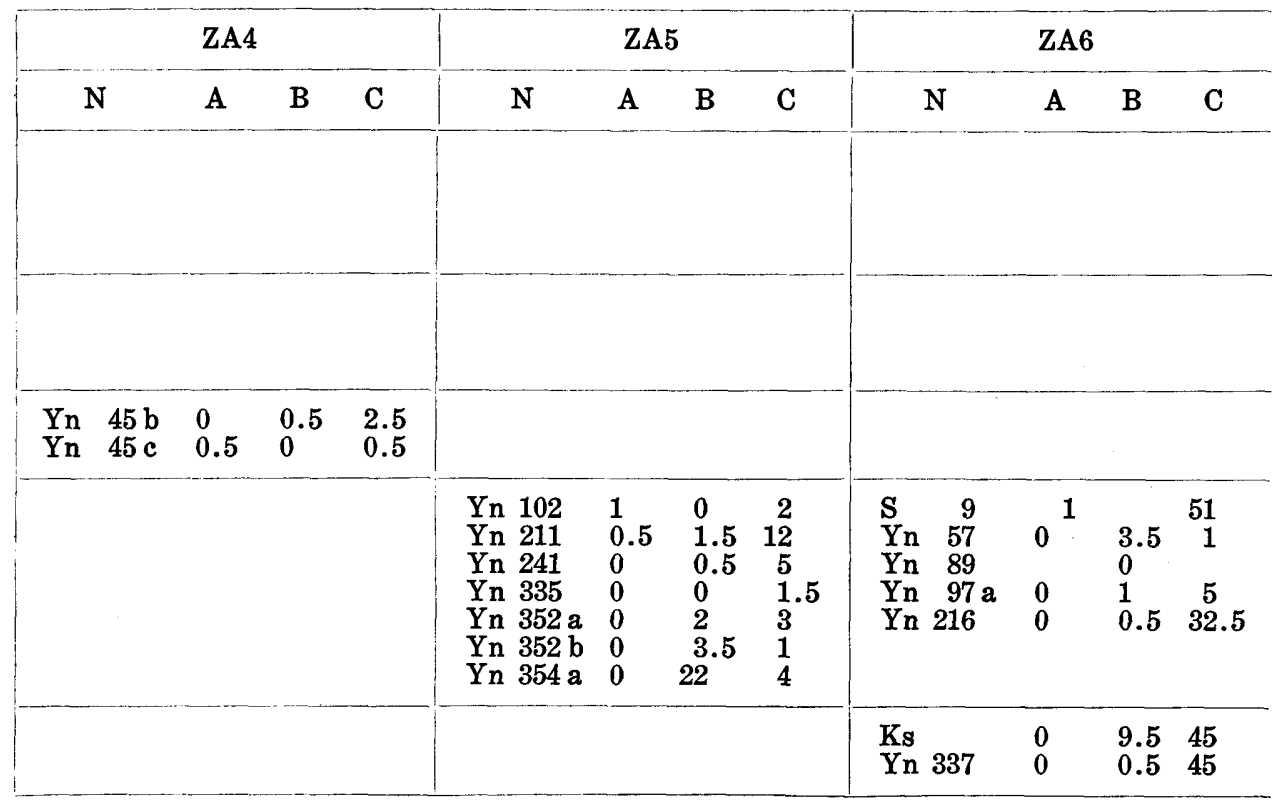

types $\mathrm{O}-\mathrm{A}, \mathrm{O}-\mathrm{B}$, and $\mathrm{O}-\mathrm{C}$ in percentage of the whole zircon concentrate

Gamano GD-A. In Z-III of the Kibe granite metamictization takes place most intensely.

\section{Overgrowths of Zircon}

\section{Classification of overgrowths}

Zircon overgrowths are often observed in the rocks of various geologic units in this area. For example, even the non-metamorphosed sediments contain a few of such crystals of detrital origin (Pl. 10, Figs. 14-16), which, together with those from the banded gneiss, are not the object of the present study; in this paper are dealt with overgrown crystals in the rocks ranging from the xenolithic gneiss to granite. They are divided into three types according to crystal forms of core and shell as shown in Table 3.

Table 3. Classification of the overgrown zircons according to crystal habit

\begin{tabular}{c|c|c|c} 
& Type O-A & Type O-B & Type O-C \\
\hline Core & $\begin{array}{c}\text { Rounded, or rarely sub- } \\
\text { angular to sharply } \\
\text { angular }\end{array}$ & $\begin{array}{c}\text { Tracht C with or with- } \\
\text { out large } x \text { Tracht } \\
\text { D or Tracht S }\end{array}$ & $\begin{array}{c}\text { Tracht C, Tracht D, or } \\
\text { Tracht S }\end{array}$ \\
\hline Shell & Tracht C with large $x$ & Tracht C or Tracht D \\
\hline
\end{tabular}

The types of crystal habit are defined by Tomita and KARAKIDA (1958, pp. 26-27). 
The type $A$ (Pl. 9, Figs. 1-11)

Almost all of the overgrown zircons of this type (O-A) have the crystal form of Z-I. It is worthy of notice that the overgrowth of this type is characterized by only one shell in striking contrast to that of the type $\mathrm{B}$ described below. Shells of the O-A zircon are generally colorless, clear, crackless, and characteristically free from inclusions, belonging to the normal zircon of TOMITA's classification (TOMITA, 1956, Fig. 2), while its cores are brownish hyacinth and usually have cracks and inclusions. It is often found that the cracks in cores do not pass into shells through the boundaries between them (Pl. 9, Fig. 4).

Surfaces of rounded cores are usually scratched, pitted, rough, and dirty with dust-like materials. These distinguishing features of the surfaces seem to make it easy to detect cores from shells, because the irregularities on rough surfaces would reflect transmitted light irregularly to reveal the boundary between cores and shells under the microscope. Rarely cores are subangular to sharply angular (Pl. 9, Figs. 7, 8). Length of cores is normally parallel to, but rarely oblique with respect to, $c$ axis of shells (Pl. 9, Figs. 9-11). There is some tendency that the last-mentioned cores are relatively small in size. Some cores consist of overgrown zircon, broken parts of which are rounded (PI. 9, Figs. 5, 6).

Chief inclusions in the cores, in order of abundance, are (1) subhedral, short or long, prisms of zircon; (2) clouds or strings of fine black dust; (3) dark brown grains with moderate pleochroism; (4) opaque materials of spherical, cylindrical, or irregular shape. It is to be noted that some opaque materials occur as nuclei in zircons.

\section{The type $B$ (Pl. 9, Figs. 12-17; Pl. 10, Figs. 1-5)}

The majority of the overgrowths of this type (O-B) are developed in Z-II, and the remainder in either Z-I or Z-III.

In most cases cores are distinctly euhedral. Sometimes rounded cores are met with, but the degree of roundness is lower than that in O-A. Dirty materials clinged to the surface of cores are less in amount than those in O-A ( $\mathrm{Pl}$. 9, Fig. 12). Rarely are found very interesting cores: core whose pyramidal termination at one end is broken off (Pl. 10, Figs. 1, 3-5); core whose $c$ axis is not parallel to that of shell (Pl. 10, Figs. 1, 2).

Shells are commonly colorless, clear, and fresh, belonging to normal zircon, but some shells, especially those of Z-II which are cloudy, brownish, irregularly crackled, and of weaker birefringence, may be, according to TomITA's classification (1956), hyacinth or malacon. It may be noted parenthetically that some shells consist of two or more separate zones (Pl. 9, Figs. 16, 17). On the other hand, most cores are probably hyacinth $\mathrm{A}$ or $\mathrm{B}$; others are hyacinth $\mathrm{C}$ (metahyacinth) or malacon (Pl. 10, Fig. 3).

Inclusions in the cores are not so large in amount but tend to be larger in size than those in O-A. They consist essentially of short or long subhedral prisms 
of zircon-like mineral, with subordinate amounts of opaque dust-like materials. On the contrary, shells, in most cases, contain no inclusion-this is a prominent character.

\section{The type $C$ (Pl. 10, Figs. 6-13)}

$\mathrm{O}-\mathrm{C}_{1}$ resembles $\mathrm{O}-\mathrm{B}$ in every respect except habit of shells. $\mathrm{O}-\mathrm{C}_{2}$, however, is unique in the nature of shell, which is very different from other overgrowth types. Thus the shell of this type is merely a thin mantle of highly metamictized zircon, which completely or sometimes partly envelopes core of hyacinth. This feature tends to representatively manifest itself in the overgrown crystals from the Kibe granite, which is the latest intrusion in this area. It may be well to mention here that in this type there is no core with pyramidal termination at one end only or with length oblique to the $c$ axis of shell as seen in other types.

\section{Distribution of the overgrown zircons}

In Table 2 the percentages of the overgrowth types to the whole zircon concentrate are disposed with reference to both the zircon assemblage to which the overgrowths belong and the enclosing rock type. This table shows that the relative proportions of the three types in zircon overgrowths vary with rock type and zircon assemblage as well, though the sum total of the percentages has no definite relation to rock type; that $\mathrm{O}-\mathrm{A}$ is confined almost entirely to $\mathrm{ZA} 1$ and $\mathrm{ZA2}$, while the bulk of $\mathrm{O}-\mathrm{C}$ is found as a constituent of ZA3 to ZA6 in the Gamano granodiorites and the Kibe granite; that $\mathrm{O}-\mathrm{B}$ is distributed among all the assemblages, its proportion for each specimen being higher in $\mathrm{ZA} 2$ and $\mathrm{ZA} 3$ and lower in ZA1, ZA4, ZA5, and ZA6.

Again, it is interesting to note that overgrowth phenomena in zircons, excluding some of $\mathrm{O}-\mathrm{C}$, may bear some relation to their crystal habit. Thus, the shells of overgrown zircons are not assigned to the habitus $M-m$ (110) is larger than $a(100)$-but either to the habitus $\mathrm{A}-a$ is larger than $m-$ or to the habitus G- $a$ and $m$ are equally developed (Tomita and KARAKIDA, 1958, p. 27). Furthermore, few, if any, overgrown zircons are present in the concentrate that contains only small amounts of zircons assigned to the habitus $A$; for example, those concentrates from the rock specimens Yn153, Yn335, and Yn89, which belong to ZA3, ZA5, and ZA6, respectively (Table 2).

\section{Consideration}

The overgrown zircons described in this paper are entirely different in appearance from ordinary zoned crystals which consist, under the microscope, of numerous fine, almost thread-like concentric bands.

TRUEMAN (1912) found in a quartzite invaded by a granite secondarily developed zircons which partly or completely envelope original detrital grains 
of zircon, and he considered that the material for the enlargement or later crystallization was, in part at least, introduced from the granite. Similar overgrowth phenomenon in zircon has been observed by different authors in different rocks: in granites by SMITHSON (1928), GROVES (1930), TYLER and others (1940), Poldervaart and Eckelmann (1955); and Poldervaart (1956); in gneisses by PRESTON (1954) and HARRIS (1959); in sedimentary rocks and sand beds by TYLER and others (1940) and HutTon (1950). In particular, PoLderVAART and ECKELMANN (1955) published splended photomicrographs of overgrown, outgrown, and aggregated zircons in the authochthonous granites from the Beartooth Mountains of Montana-Wyoming and considered prevalence of zircons with such growth phenomena in granites formed in situ as a convincing laboratory evidence of the reality of Read's granite series.

But to return to our subject, many of the cores of O-B and $\mathrm{O}-\mathrm{C}_{1}$ are sharply euhedral, consisting chiefly of $a(100)$ and $p(111)$ with poor development of $m(110)$ and $x(311)$. This morphological characteristic of the cores is invariant throughout the granitic complex under consideration. PoldervaArT (1956) and the authors cited in his paper, Alper and PoldervaArT (1957), and TAubeNECK (1957) ascertained the fact that zircons from normal granite exhibit the same morphological feature throughout a granite mass. Thus, assuming that such uniformity and sharpness of crystal form are regarded as evidence for magmatic origin of zircon, it appears to be permitted that the cores of $\mathrm{O}-\mathrm{B}$ and $\mathrm{O}_{1} \mathrm{C}_{1}$ were crystallized from a granitic magma.

The cores of O-A are well-rounded, and this type of zircon overgrowths occurs exclusively in the xenolithic banded gneisses but less granitized-these facts may indicate that the cores are relicts of original detrital zircon. In addition, the observations that some of the rounded cores again contain sharply terminated zircon as nuclei (Pl. 9, Figs. 5, 6) and that the cores of this type are far more rounded than the detrital zircons in the non-metamorphosed sediments of this area may support the conception that further corrosion of detrital zircons took place to some extent before the formation of outer shells. The phenomena impressed on the cores of $\mathrm{O}-\mathrm{A}$, such as corrosion, dirtying the corroded surface, breakage, crossing of the $c$ axes for core and shell, etc. are interpreted as indicating that there was a break in zircon generation-a break corresponding with a period during which zircon grains were chemically reacted with and also were moved to and fro through the surrounding medium.

The cores of $\mathrm{O}-\mathrm{B}$ and $\mathrm{O}-\mathrm{C}_{1}$ show the same phenomena as those of $\mathrm{O}-\mathrm{A}$ mentioned above but not so markedly advanced. This fact seems to imply differences in both crystallization condition and time lapse of the break in generation between cores and shells, a greater time lapse being demanded for O-A. As previously mentioned, both cores and shells of $\mathrm{O}-\mathrm{B}$ and $\mathrm{O}-\mathrm{C}_{1}$ are considered to be of magmatic origin on the basis of sharpness of their edges and terminals, and the morphological difference between cores and shells in O-B suggests that their crystallization conditions are somewhat different from each other. Furthermore, the development of two or more zones in the shells of O-B and O- $\mathrm{C}_{1}$, does 
not imply continuous calm crystallization.

The absence of inclusions in the shells of $\mathrm{O}-\mathrm{B}$ and $\mathrm{O}-\mathrm{C}_{1}$ as well as $\mathrm{O}-\mathrm{A}$ is one of the noteworthy features different from common zircons in granites. Though this may indicate a comparatively rapid crystallization of the shells, much more research is necessary before the subject can be explained.

The mode of origin for the types $A(\mathrm{O}-\mathrm{A}), \mathrm{B}(\mathrm{O}-\mathrm{B})$, and $\mathrm{C}_{1}\left(\mathrm{O}-\mathrm{C}_{1}\right)$ of zircon overgrowths mentioned above may lead to the following petrogenic concept: such rocks as containing the overgrown crystals were originated by mixing of sediments, which had detrital zircons now seen as relict cores of O-A, and granitic liquids, which were crystallizing euhedral zircons now seen as relict cores of $\mathrm{O}-\mathrm{B}$ and $\mathrm{O}-\mathrm{C}_{1}$ as well as parts of $\mathrm{O}-\mathrm{A}$. In the rocks rich in $\mathrm{O}-\mathrm{A}$ (xenolithic banded gneisses and ôbatake granodiorites characterized by the zircon assemblages 1 and 2 ) the original solid sedimentary material might be comparatively predominant, while in the rocks rich in $\mathrm{O}-\mathrm{B}$ and $\mathrm{O}-\mathrm{C}_{1}$ (ôbatake and Gamano granodiorites characterized by the zircon assemblages 3 to 6 ) the granitic liquid may have been incorporated in relatively great amounts. This conclusion may be supported by a greater amount of zircon crops in the latter group of rocks than in the former, because granitic magmas generally contain more zirconium to form zircon than sediments.

The subsequent marked changes of environment after the mixing just mentioned made the cores round and promoted the new growth of shells which differ entirely from the cores in crystal habit, inclusion, etc. During the crystallization of the shells, parts of the ôbatake (zircon assemblage 3 ) and Gamano granodiorites sometimes underwent changes of condition which may be due to local and intermittent contamination of granitic magma by small blocks of preexisting gneiss and to successively repeated permeation of other new granitic magmas, as indicated by the presence of two or more zones in the shells of $\mathrm{O}-\mathrm{B}$ and $\mathrm{O}-\mathrm{C}_{1}$. Such processes cannot be clearly analyzed by ordinary laboratory work on the present rock specimens. Lastly, the malacon mantle of $\mathrm{O}-\mathrm{C}_{2}$ is thought to be crystallized from the acid magma which represents the latest stage of magmatic evolution.

Detailed studies of the zircon overgrowths would refresh our knowledge of the processes in the formation of granitic rocks.

\section{References Cited}

Alper, A. M., and Poldervaart, Arie (1957): Zircons from the Animas stock and associated rocks, New Mexico. Econ. Geol., 52, 952-971.

Groves, A. W. (1930): The heavy mineral suites and correlation of the granites of Northern Brittany, the Channel Island and Cotentin. Geol. Mag., 67, 218-240.

HARRIS, R. L., Jr. (1959): Geologic evolution of the Beartooth Mountains, Montana and Wyoming. Part 3. Gardner Lake Area, Wyoming. Bull. Geol. Soc. Am., 70, 635-710.

Hutron, C. O. (1950): Studies of heavy detrital minerals. Bull. Geol. Soc. Am., 61, 635-710.

IwAo, Shûichi (1936): The field relations between granites and the Ryôke metamor- 
phic rocks in the Yanai district. Jour. Geol. Soc. Japan, 43, 660-691 (in Japanese).

IwA0, Shûichi (1940): The origin of the basic inclusions in the granitic rocks of the Yanai district, Japan, and their petrographic features. Japanese Jour. Geol. Geogr., 17, 45-62.

KoJima, George (1953): Contributions to the knowledge of mutual relations between three metamorphic zones of Chugoku and Shikoku, Southwest Japan, with special reference to the metamorphic and structural features of each metamorphic zone. Jour. Sci., Hiroshima Univ., Ser. C (Geology), 1, 17-46.

KoJima, George, and Okamura, Yoshihiko (1952): "The Yanai District." Guide-book of the Excursion at the 59th Ann. Meet. Geol. Soc. Japan. Dept. Geol., Kyushu Univ., 18 p. (in Japanese).

Krumbein, W. C., and Pettijohn, F. J. (1938) : Manual of Sedimentary Petrography (New York, D. Appleton-Century Co.). $549 \mathrm{p}$.

Okamura, Yoshihiko (1957): Structure of the Ryôke metamorphic and granodioritic rocks of the Yanai district, Yamaguchi Prefecture. Jour. Geol. Soc. Japan, 63, 684-697 (in Japanese with English abstract).

PoldervaArt, Arie (1955): Zircons in rocks. 1. Sedimentary rocks. Am. Jour. Sci., 253, 433-461.

(1956) : Zircon in rocks. 2. Igneous rocks. Am. Jour. Sci., 254, 521-554.

PoldervaArt, Arie, and Eckelmann, F. D. (1955): Growth phenomena in zircon of authochthonous granites. Bull. Geol. Soc. Am., 66, 947-948.

Preston, John (1954): The geology of the pre-Cambrian rocks of the Kuopio district. Soumalaisen Tiedeakatemian Toimituksis Annales Acad. Sci. Fennicae, Ser. A, III, Geol.-Geogr., 40, 1-111.

Sato, Moto-o (1933) : "Yanaizu." Expl. Text of the Geol. Map of Japan, 1/75,000. Geol. Surv. Japan (in Japanese with English abstract).

Smithson, Frank (1928): Geological studies in the Dublin district-1. The heavy minerals of the granite and the contiguous rocks in the Ballyeorus district. Geol. Mag., 65, 12-25.

Taubeneck, W. H. (1957) : Geology of the Elkhorn Mountains, Northeastern Oregon; Bald Mountain batholith. Bull. Geol. Soc. Am., 68, 181-238.

Tomita, Tôru (1956): The radio-effects in zircon. The Earth Science, Nos. 26-27, 36-51 (in Japanese).

Tomita, Tôru, and Karakida, Yoshifumi (1956): A simple method for separating accessory zircons. The Earth Science, No. 29, 20-26 (in Japanese).

, and (1958): Source identification of some granitic xenoliths in volcanic rocks. Mem. Fac. Sci., Kyushu Univ., Ser. D (Geology), 8, 25-34.

Trueman, J. D. (1912): The value of certain criteria for the determination of the origin of foliated crystalline rocks. Jour. Geol., 20, 228-258.

Tyler, S. A., Marsden, R. W., Grout, F. F., and Thiel, G. A. (1940) : Studies of the Lake Superior pre-Cambrian by accessory-mineral method. Bull. Geol. Soc. Am., 51, 1429-1538. 
Plate 9 


\section{Explanation of Plate 9}

Figs. 1-11: Zircon overgrowths designated as type A from the xenolithic banded gneiss and the Gamano granodiorite.

Note core with fractures independent of shell (Fig. 4); corroded cores containing zircon nuclei (Figs. 5, 6); cores with $c$ axis oblique to length of shell (Figs. 9-11).

Figs. 12-17: Zircon overgrowths (type B) from the xenolithic banded gneiss and the Ôbatake and Gamano granodiorites.

Note cores with two or more separate shells (Figs. 16, 17). 

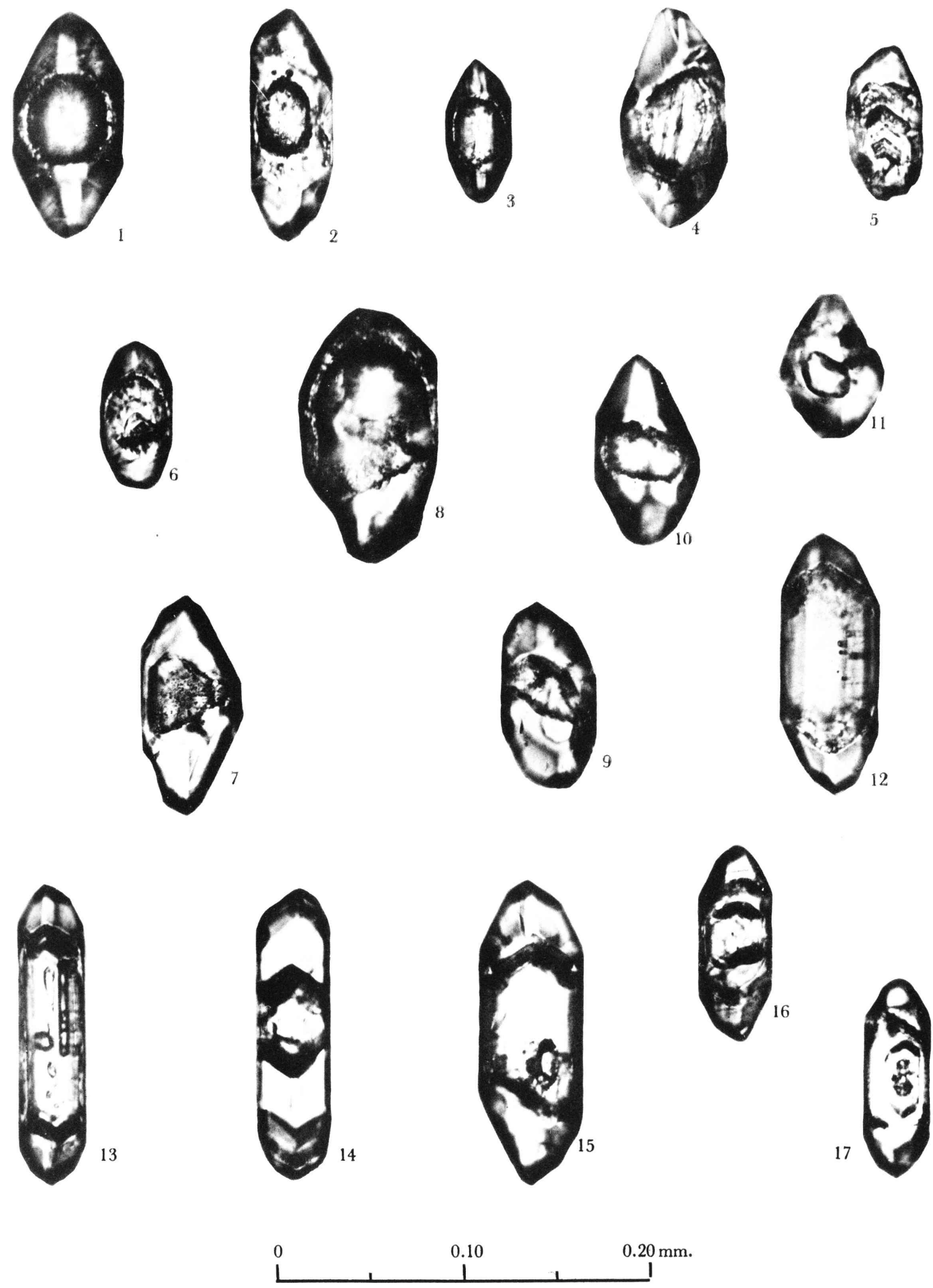
Plate 10 


\section{Explanation of Plate 10}

Figs. 1-5: Zircon overgrowths (type B) from the xenolithic banded gneiss and the Ôbatake and Gamano granodiorites.

Note cores with $c$ axis oblique to length of shell (Figs. 1,2) and cores with only one pyramidal termination (Figs. 1, 3-5).

Figs. 6-10: Zircon overgrowths (type $\mathrm{C}_{1}$ ) from the Gamano granodiorite.

Note cores with two or more separate shells (Figs. 6, 7).

Figs. 11-13: Zircon overgrowths (type $\mathrm{C}_{2}$ ) from the Kibe granite.

Figs. 14-16: Zircon overgrowths from slate and sandstone of the non-metamorphosed sediment zone. 

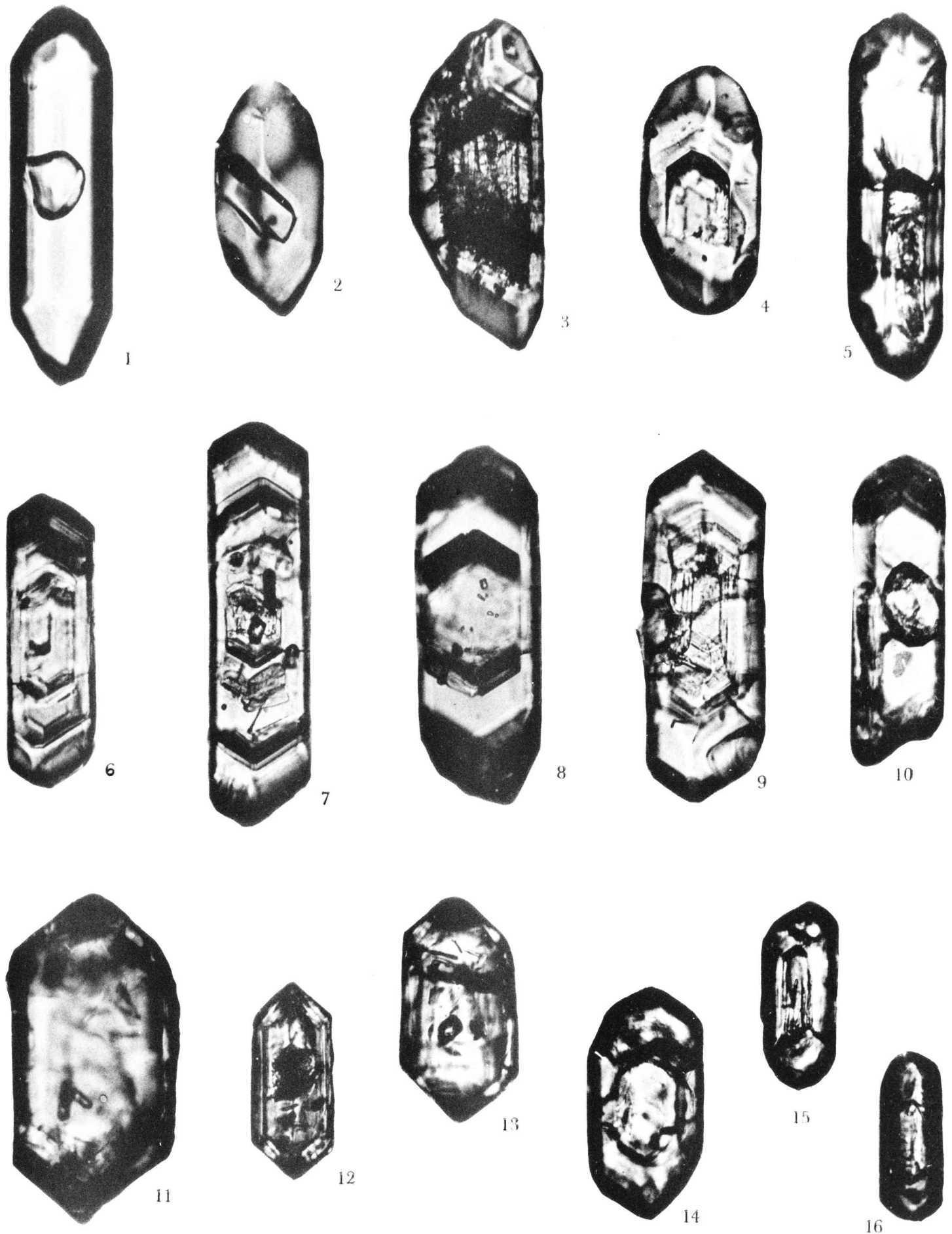